\title{
Tipe Fluida Hidrotermal Sepanjang Manifestasi Panas Bumi di Daerah Ungaran dan Sekitarnya
}

\author{
Paramitha Tedja Trisnaning ${ }^{1}$, Fatimah ${ }^{2}$ \\ 1,2 Program Studi Teknik Geologi, Fakultas Teknologi Mineral, \\ Institut Teknologi Nasional Yogyakarta \\ Email: mitha@itny.ac.id
}

Received: April 14, 2021; Accepted : August 3, 2021; Published : November 1, 2021

\begin{abstract}
ABSTRCT
The east-south part of Mount Ungaran, Central Java is known as a geothermal prospect area, with its warm - hot springs geothermal manifestations. The local community and government develop the manifestation as tourist area or hot spring/pool which can be found in the tourist areas of Gedongsongo, Diwak, Derekan, Kaliulo, and Banaran. Manifestations appear on the surface with different temperatures and characteristics. Possibly, due to the different types of hydrothermal fluid. Hence, it is interesting to determine the type of hydrothermal fluid based on its anion content- $\mathrm{Cl}^{-}, \mathrm{SO}^{2-}$, and $\mathrm{HCO}^{3-}$. Hydrothermal fluids appear on the surface as alkaline chloride water, sulfuric acid water, sulfuric-hydrochloric acid water, and bicarbonate water. The results of the anion concentration analysis at the five locations, showed the highest $\mathrm{Cl}^{-}$concentration $( \pm 4,475 \mathrm{ppm})$ was found at Diwak hot spring, it is also represented with $\mathrm{HCO}^{3-}$ concentrations of $127-500$ ppm and relatively low of SO4 ${ }^{2-}$. Gedongsongo, Derekan, Kaliulo, and Banaran hot springs were formed by bicarbonate water and Diwak hot spring was formed by chloride water.
\end{abstract}

Keywords:Ungaran, Diwak, hydrothermal fluid

\begin{abstract}
ABSTRAK
Bagian timur-selatan kaki Gunung Ungaran, Jawa Tengahdikenal sebagai daerah prospek panasbumi dengan manifestasi panasbumi matair hangat - panas. Masyarakat maupun pemerintah setempat, memanfaatkan manifestasi tersebut sebagai area wisata ataupun pemandian/kolam air panas yang dapat dijumpai di area wisata Candi Gedongsongo, Diwak, Derekan, Kaliulo, dan Banaran. Manifestasi matair panas muncul di permukaan dengan suhu dan karakteristik yang berbeda. Hal ini dimungkinkan karena adanya perbedaan tipe fluida hidrotermal, sehingga menarik dilakukan penentuan tipe fluida hidrotermalberdasarkan kandungan anionnya- $-\mathrm{Cl}^{-}, \mathrm{SO}_{4}{ }^{2-}$, dan $\mathrm{HCO}_{3}{ }^{-}$. Fluida hidrotermal muncul di permukaan sebagai air alkali klorida, air asam sulfat, air asam sulfat-klorida, dan air bikarbonat.Hasil analisis konsentrasi anion pada ke-lima lokasi, menunjukkan konsentrasi $\mathrm{Cl}^{-}$ tertinggi $\pm 4.475 \mathrm{ppm}$ dijumpai pada matair panas Diwak dengan konsentrasi $\mathrm{HCO}_{3}{ }^{-} 127-500 \mathrm{ppm}$ dan $\mathrm{SO}_{4}{ }^{2-}$ relatif rendah. Tipe fluida hidrotermal mataair panas Gedongsongo, Derekan, Kaliulo, dan mataair Banaran berupa Air Bikarbonat, serta mataair panas Diwak berupa Air Klorida.
\end{abstract}

Kata Kunci :Ungaran, Diwak, fluida hidrotermal

\section{PENDAHULUAN}

Gunung Ungaran sebagai gunungapi tipe B [1]—tidak pernah mengalami erupsi setelah tahun 1600—dikenal dengan daerah wisata pemandian atau kolam mataair panas. Daerah Gunung Ungaran dan sekitarnya telah sejak lama dikenal sebagai daerah prospek panasbumi, terutama dijumpai di bagian timur - selatan kaki Gunung Ungaran, Kabupaten Semarang, Propinsi Jawa Tengah [2]. Sepanjang daerah tersebut terbentuk sejumlah manifestasi panasbumi, baik berupa fumarol, kolam air panas, steaming ground maupun altered ground[2] [3]. Pada umumnya, manifestasi panasbumi yang berkembang berupa matair hangat hingga panas, diantaranya mataair panas Gedongsongo, Diwak, Derekan, Kaliulo, dan mataair Banarandengan karakteristik endapan yang berkembang berupa sulfur dan travertin.

Manifestasi panasbumi tersebut, tampak muncul pada Formasi Kaligetas, Batuan Gunungaapi Gajahmungkur, dan Lava Gunung Sumbingdengan penyebaran batuan pada bagian timur - tenggara - selatan kaki Gunung Ungaran (Gambar 1). Formasi Kaligetas, tersusun atas breksi vulkanik, aliran lava, tuf, batupasir tufan, dan batulempung. Selain itu, tersusun pula atas breksi aliran dan lahar dengan sisipan lava dan tuf halus - kasar. Setempat pada bagian bawah dijumpai batulempung mengandung moluska dan batupasir tufan [4].Batuan Gunungaapi Gajahmungkurdijumpai melampar dari puncak hingga sisi selatan - timur - tenggara Gunung Ungaran, tersusun atas aliran lava andesithornblenda-augit. Lava Gunung Sumbingdengan pelamparan dari puncak Gunung 
Ungaran ke arah baratdaya - selatan dan pada bagian tenggara Gunung Ungaran, tersusun atas aliran lava dan kubah horblenda-augit [4].

Dipengaruhi berbagai kondisi, manifestasi matair panasdapat muncul di permukaan dengan kadar suhu dan karakteristik yang berbeda, serta dapat mengindikasikantipe fluida hidrotermal maupun sumber fluida tertentu.Fluida hidrotermal dapat muncul di permukaan sebagai air alkali klorida, air asam sulfat, air asam sulfatklorida, dan air bikarbonat dengan sumber fluida dapat berupa air reservoir, air magmatik maupun uap air panas atau kondensat yang ditentukan berdasarkan kandungan prosentase anion klorida, sulfat, dan bikarbonat [5].Bahkan, dapat diperkirakan kondisi suhu di bawah permukaan berdasarkan tipe fluida dan karakteristik endapan yang berkembang di sekitar manifestasi panasbumi.

Penelitian dilakukan dengan tujuan pengamatan dan penentuan tipe fluida hidrotermal pada mataair di daerah Ungaran, khususnya pada bagian timur - selatan kaki Gunung Ungaran. Melalui penelitian diharapkan dapat ditentukan sumber fluida maupun suhu bawah permukaanyang berpengaruh dalam pembentukan manifestasi panasbumi.Penentuan tipe dan sumber fluida hidrotermal dilakukan berdasarkan diagram ternary $\mathrm{Cl}^{-}-\mathrm{SO}_{4}{ }^{2-}-$ $\mathrm{HCO}_{3}{ }^{-}[5]$.

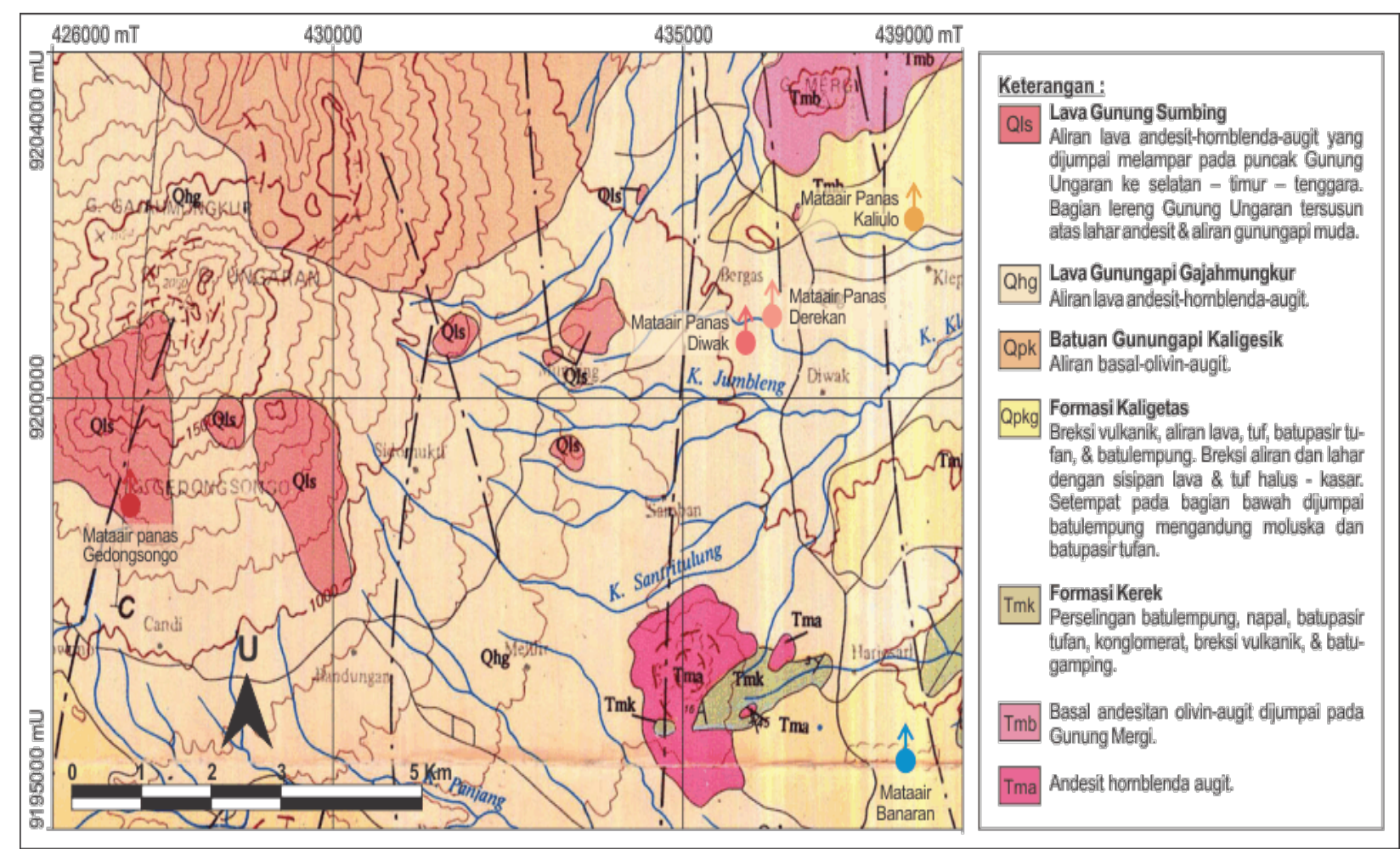

Gambar 1. Titik lokasi penelitian berdasarkan keberadaan manifestasi mataair pada bagian timur - selatan kaki Gunung Ungaran di sepanjang Gedongsongo, Diwak, Derekan, Kaliulo, dan Banaran [4].

\section{METODE PENELITIAN}

Penelitian dilakukan secara deskriptif evaluatif dan kuantitatif.Penelitiandeskriptif evaluatif merupakan evaluasi kondisi obyek studi secara apa adanya dengan obyek studi berupa manifestasi mataair panas maupun mataair bersuhu rendah.Penelitian secara deskriptif evaluatif dilakukan pada saat pengamatan maupun pengumpulan conto air di lapangan.Penelitian kuantitaif terutama dilakukan dalam analisis konsentrasi anion maupun analisis tipe fluida hidrotermal di sepanjang Gedongsongo, Diwak, Derekan, Kaliulo, dan Banaran.

Tahapan penelitian sebagaimana ditunjukkan pada Gambar 2, diawali dengan studi literatur atau mengumpulkan, memilah, dan mengelompokan data sekunder serta menentukan metode penelitian yang akan dilakukan. Selanjutnya, dilakukan pengamatan lapangan, pengumpulan data, dan pengambilan conto air yang dilakukan pada lima lokasi mataair, yaitu mataair panas Gedongsongo, Diwak, Derekan, Kaliulo, dan mataair Banaran (Gambar 1). Pengambilan conto air dilakukan sebanyak $\pm 200 \mathrm{ml}$ pada setiap lokasi mataair.

Tahap berikutnya, dilakukan analisis terhadap conto air dari ke-lima mataair menggunakan Metode HPLC atau High Performance Liquid Chromatography pada laboratorium BATAN, Yogyakarta guna menentukan nilai konsentrasi anion utama- $\mathrm{Cl}^{-}, \mathrm{SO}_{4}{ }^{2-}$ dan $\mathrm{HCO}_{3}{ }^{-}$(Gambar 2).Metode HPLC merupakan suatu teknik dalam kimia analis yang digunakan untuk memisahkan, mengidentifikasi, dan menghitung setiap komponen yang terkandung 
Tipe Fluida Hidrotermal Sepanjang Manifestasi Panas Bumi di Daerah Ungaran dan Sekitarnya

dalam suatu campuran fluida [6].Berdasarkan hasil analisis dapat ditentukan secara kuantitatif konsentrasi masingmasing komponen, dalam hal ini konsentrasi anion utama penyusun fluida hidrotermal.Analisis dilakukan terhadap ke-lima conto air dari setiap lokasi mataair dengan jumlah \pm 100 mlper conto air.

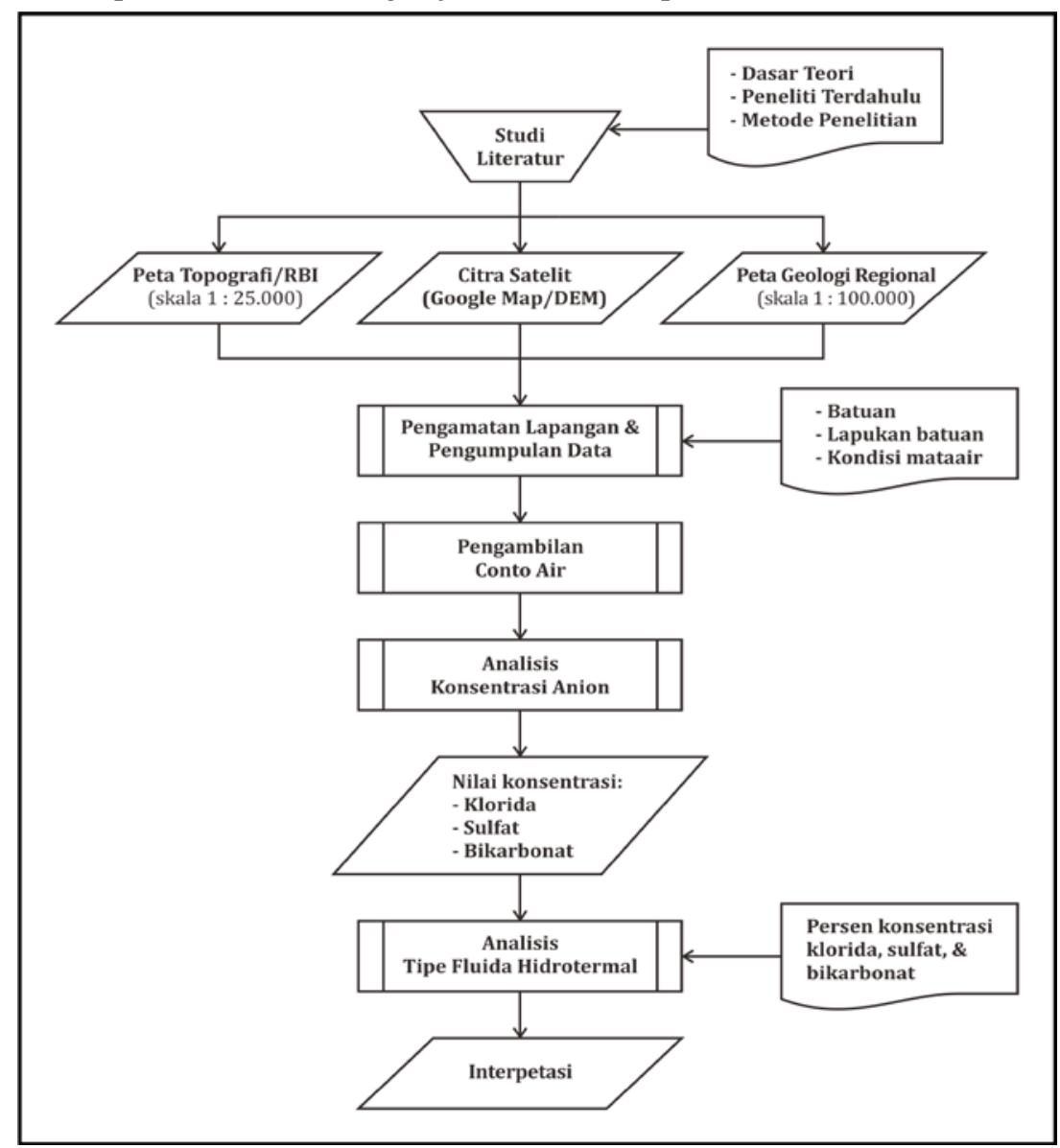

Gambar 2. Diagram alir penelitian terkait penentuan tipe fluida hidrotermal di sepanjang Gedongsongo, Diwak, Derekan, Kaliulo, dan Banaran.

Sebagaimana ditunjukkan pada Gambar 2, tahap selanjutnya dilakukan analisis tipe fluida hidrotermalberdasarkan perbandingan persen konsentrasi klorida, sulfat, dan bikarbonat yang diperoleh melalui persamaan berikut[5].

a) Penjumlahan konsentrasi klorida, sulfat, dan bikarbonat.

$\mathrm{Cl}^{-}+\mathrm{SO}_{4}{ }^{2-}+\mathrm{HCO}_{3}{ }^{-}=\Sigma$

b) Penentuan perbandingan persen relatif dari konsentrasi klorida, sulfat, dan bikarbonat.

$\% \mathrm{Cl}^{-}=\left(\mathrm{Cl}^{-} / \Sigma\right) 100 ; \% \mathrm{SO}_{4}{ }^{2-}=\left(\mathrm{SO}_{4}{ }^{2-} / \Sigma\right) 100 ; \mathrm{dan} \% \mathrm{HCO}_{3}{ }^{-}=\left(\mathrm{HCO}_{3}{ }^{-} / \Sigma\right) 100$

Interpretasitipe dan sumber fluida hidrotermaldi sepanjang Gedongsongo, Diwak, Derekan, Kaliulo, dan Banaran ditentukan berdasarkanhasil plotingnilai persen konsentrasi klorida, sulfat, dan bikarbonat pada diagram ternary $\mathrm{Cl}^{-}-$ $\mathrm{SO}_{4}{ }^{2-}-\mathrm{HCO}_{3}{ }^{-}[5]$, sebagaimana ditunjukkan pada Gambar 3.

\section{HASIL DAN ANALISIS}

\subsection{Kondisi Geologi Lokasi Mataair}

Titik lokasi penelitian berada pada kaki Gunung Ungaran bagian selatan - tenggara (Gambar 1), termasuk dalam fisiografi regional Gunung Ungaran [7]. Gunung Ungaran merupakan komplek gunungapi yang terbentuk akibat depresi tektonik-gunungapi (volcano-tectonic depression). Berdasarkan bentuk atau geometrinya, Gunung Ungaran termasuk jenis strato atau memiliki bentuk kerucut yang umumnya terbentuk sebagai hasil erupsi yang berubah-ubah dan membentuk susunan lapisan beberapa jenis batuan.

Setiap manifestasi mataair panas pada daerah penelitian dijumpai pada kondisi geomorfologi yang berbeda. Mataair panas Gedongsongo berkembang pada satuan geomorfologi Aliran Lava Ungaran Muda [8]. Lokasi pengamatan mataair panas Gedongsongo terletak dalam komplek wisata Candi Gedongsongo, lereng selatan 
Gunung Ungaran. Mataair tersebut berkembang disepanjang jalur Sesar Panjang yang berarah relatif utara - selatan pada sisi selatan Gunung Ungaran [4] [9], sebagaimana ditunjukkan pada Gambar 1. Mataair tampak mengalir melalui retakan pada batuan lava andesit maupun melalui lapukan atau material hasil alterasi. Lava andesit sebagai bagian dari Lava Gunung Sumbing (Gambar 1), dijumpai dalam kondisi relatif segar pada bagian utara. Semakin ke arah selatan, tampak tertutup tanah tebal dan dijumpai lempung yang diperkirakan sebagai produk alterasi berupa mineral kelompok argilit [3] [10]. Sedikitnya terdapat tiga mataair dengan salah satunya telah dikembangkan menjadi kolam pemandian. Mataair memiliki suhu sedang hingga panas atau sekitar $61^{\circ}-89^{\circ} \mathrm{C}$ [3] dengan beberapa diantaranya mengeluarkan solfatara dan terbentuk endapan belereng berwarna kekuningan di sekitarnya.

Ke-empat manifestasi mataair panas lainnya, baik mataair Diwak, Derekan, Kaliulo maupun Banaran dijumpai pada satuan geomorfologi Endapan Piroklastik Ungaran Muda [8]. Mataair Diwak dan Derekan memiliki karakter suhu relatif hangat. Hanya saja yang membedakan, pada daerah di sekitar mataair Derekan terdapat adanya travertin. Kedua mataair terbentuk pada tanahhasil lapukan maupun alterasi lava andesit dari Lava Gunungapi Gajahmungkur (Gambar 1). Masyarakat setempat memanfaatkan dan mengembangkan kedua mataair tersebut sebagai wisata kolam pemandian airpanas. Namun, seiring waktu kedua mataair tersebut telah mengalami penurunan suhu.

Mataair panas Kaliulo dan mataair Banaran dijumpai berkembang pada satuan batuan batupasir tufan dan batulempung Formasi Kaligetas (Gambar 1). Matair Kaliulo, berada pada bagian timurlaut kaki Gunung Ungaran, dijumpai berkembang pada lahan pertanian dengan kemiringan bergelombang lemah hingga landai. Manifestasi panasbumi yang terbentuk berupa kolam lumpur dengan suhu relatif tinggi disertai dengan keluarnya fumarol. Pada aliran sungai, tampak terbentuk travertin yang memanjang melintang tubuh sungai. Lokasi pengamatan terakhir, mataair Banaran terletak di daerah Banaran pada kaki Gunung Ungaran bagian tenggara. Mataair muncul di tengah lahan persawahan pada beberapa tempat yang saling berdekatan dengan suhu relatif rendah atau relatif dingin. Pada salah satu matair dengan debit besar, oleh masyarakat setempat dialirkan pada bak penampungan untuk dimanfaatkan dalam pengairan lahan disekitar mataiar maupun memenuhi kebutuhan air bersih.

\subsection{Hasil}

Penentuan tipe dan sumber fluida hidrotermal dilakukan berdasarkan analisis konsenstrasi anion dan analisis tipe fluida hidrotermal terhadap lima conto air yang masing-masing diambil pada mataair Gedongsongo, Diwak, Derekan, Kaliulo, dan Banaran.Hasil analisis menunjukkan konsentrasi sulfat relatif rendah dibandingkan konsentrasi klorida dan bikarbonat (Tabel 1). Nilai konsentrasi tertinggi ditunjukkan pada klorida mataair Diwak sebesar 4.475 ppm (Tabel 1) atau 99,8\% (Tabel 2) dengan nilai konsentrasi klorida pada lokasi pengamatan lain relatif rendah. Nilai konsentrasi klorida terendah dijumpai pada mataair panas Gedongsongo dan mataair Banaran sekitar 0,928 ppm (Tabel 1) atau 0,5\% (Tabel 2). Konsentrasi bikarbonat, pada sebagian besar lokasi pengamatan menunjukkan nilai relatif tinggi sebesar 127 ppm hingga 500 ppm (Tabel 1) atau 71\% hingga 96,7\% (Tabel 2).

Tabel 1. Nilai konsentrasi klorida,sulfat, dan bikarbonat ke-lima conto air.

\begin{tabular}{ccccc} 
& \multirow{2}{*}{$\begin{array}{c}\text { Lokasi } \\
\text { mo. }\end{array}$} & \multicolumn{3}{c}{ Parameter $(\mathrm{ppm})$} \\
\cline { 3 - 5 } & Gedongsongo & $\leq 0,928$ & 50,318 & 127,143 \\
\hline 1. & Diwak & 4474,940 & $\leq 4,328$ & $\leq 3,88$ \\
\hline 2. & Derekan & 51,462 & $\leq 4,328$ & 428,571 \\
\hline 3. & Kaliulo & 63,395 & $\leq 4,328$ & 500,000 \\
\hline 4. & Banaran & $\leq 0,928$ & $\leq 4,328$ & 150,714 \\
\hline 5. & & & & \\
\hline
\end{tabular}


Tipe Fluida Hidrotermal Sepanjang Manifestasi Panas Bumi di Daerah Ungaran dan Sekitarnya

Tabel 2. Nilai persen konsentrasi klorida $\left(\mathrm{Cl}^{-}\right)$, sulfat $\left(\mathrm{SO}_{4}{ }^{2-}\right)$, dan bikarbonat $\left(\mathrm{HCO}_{3}{ }^{-}\right)$dari setiap conto air.

\begin{tabular}{ccccc} 
& \multirow{2}{*}{$\begin{array}{c}\text { Lokasi } \\
\text { No. }\end{array}$} & Parameter (\%) \\
\cline { 3 - 5 } & Gedongsongo & 0,5 & $\mathrm{SO}_{4}{ }^{2-}$ & $\mathrm{HCO}_{3}{ }^{-}$ \\
\hline 1. & Diwak & 99,8 & 28,5 & 71 \\
\hline 2. & Derekan & 10,8 & 0,1 & 0,1 \\
\hline 3. & Kaliulo & 11,3 & 0,8 & 88,3 \\
\hline 4. & Banaran & 0,6 & 2,7 & 88 \\
\hline 5. & & & & 96,7 \\
\hline
\end{tabular}

Analisis tipe fluida hidrotermal berdasarkan hasil analisis konsentrasi anion dan plotting pada diagram ternary $\mathrm{Cl}^{-}-\mathrm{SO}_{4}{ }^{2-}-\mathrm{HCO}_{3}{ }^{-}[5]$ menunjukkan sebagian besar mataair yang berkembang pada daerah Ungaran memiliki tipe fluida hidrotermal berupa Air Bikarbonat (Gambar 2), dijumpai pada mataair Gedongsongo, Derekan, Kaliulo, dan Banaran. Hal tersebut dikontrol atas konsentrasi anion utama lebih kurang 5,8 \% $\mathrm{Cl}^{-}, 8,2 \% \mathrm{SO}_{4}{ }^{2-}$, dan $86 \%$ $\mathrm{HCO}_{3}^{-}$(Tabel 2). Berbeda dengan ke-empat mataair lainnya, mataair Diwak memiliki konsentrasi anion utama sebesar $\pm 99,8 \% \mathrm{Cl}^{-}, \mathrm{SO}_{4}{ }^{2-}$, dan $\mathrm{HCO}_{3}{ }^{-}$masing-masing sebesar 0,1\%. Berdasarkan hasil ploting pada diagram ternary $\mathrm{Cl}^{-}-\mathrm{SO}_{4}{ }^{2-}-\mathrm{HCO}_{3}{ }^{-}[5]$, tipe fluida hidrotermal mataair Diwak berupa Air Klorida. Persebaran mataair beserta konsentrasi kimia dan tipe fluida hidrotermal ditunjukkan pada Gambar 4.

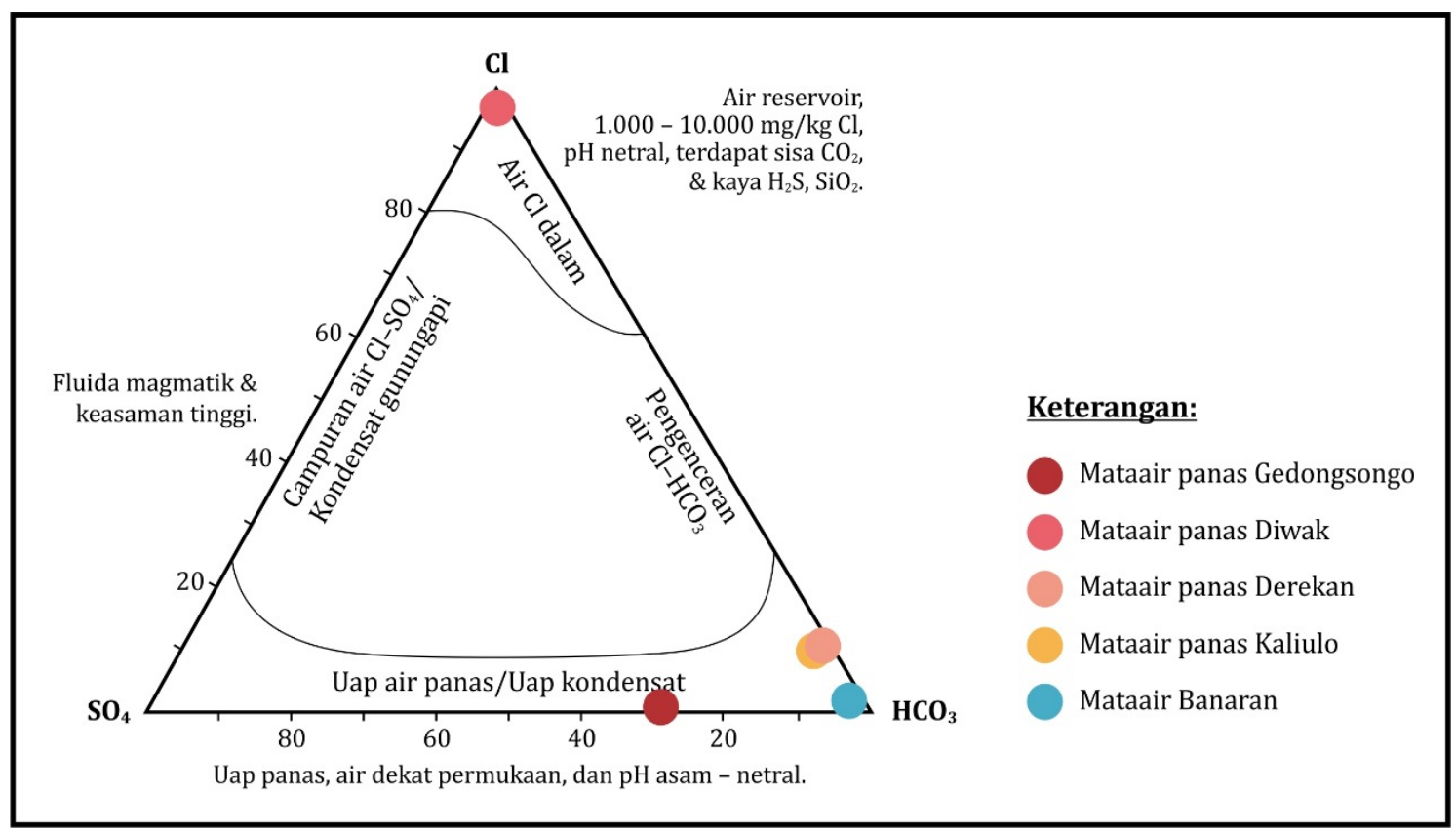

Gambar 3. Analisis tipe fluida hidrotermal berdasarkan ploting persen konsentrasi klorida $\left(\mathrm{Cl}^{-}\right)$, sulfat $\left(\mathrm{SO}_{4}{ }^{2-}\right)$, dan bikarbonat $\left(\mathrm{HCO}_{3}{ }^{-}\right)$dari mataair panas Gedongsongo, Diwak, Derekan, Kaliulo, dan mataair Banaran. 


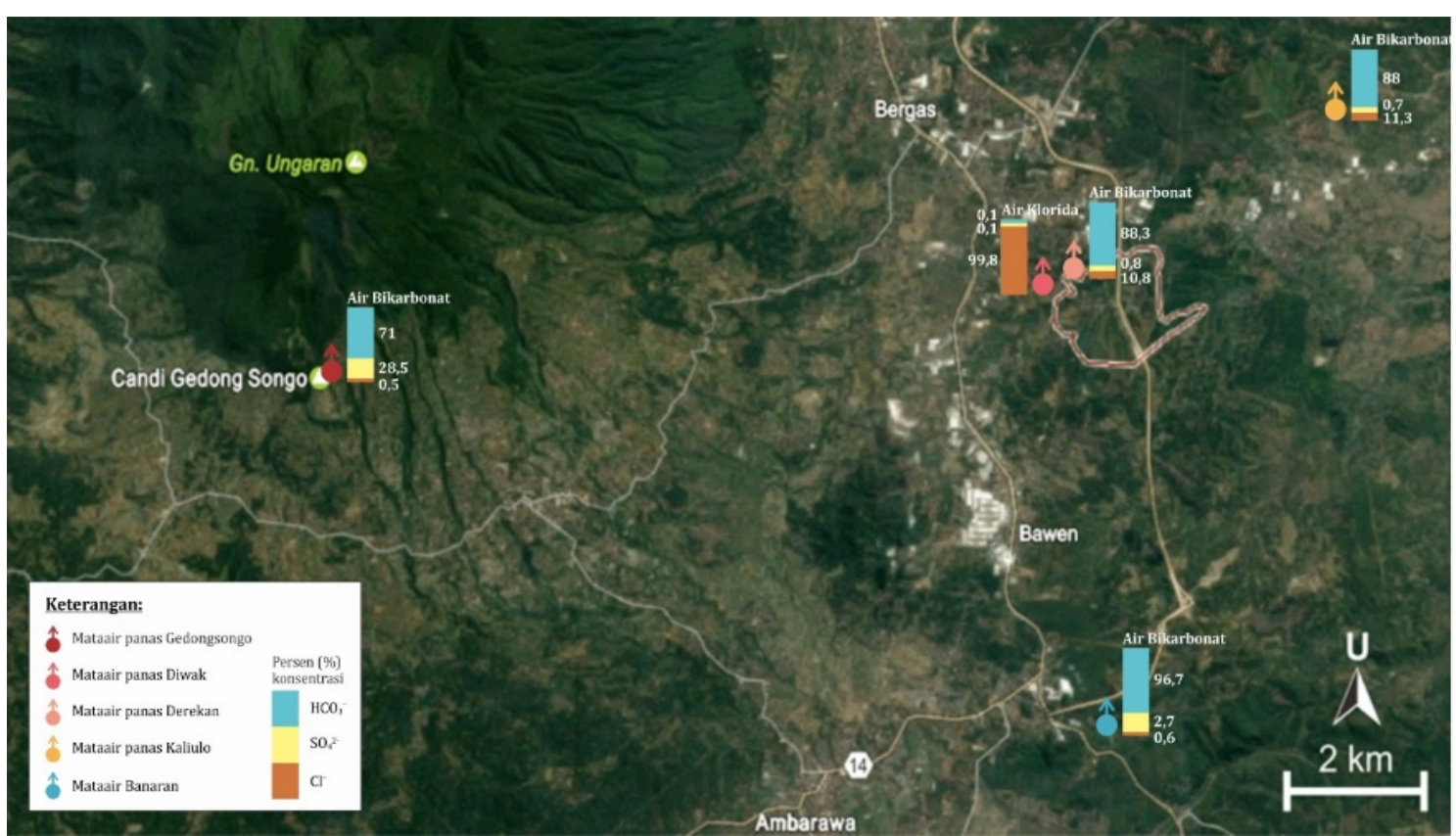

Gambar 4. Persebaran variasi konsentrasi klorida $\left(\mathrm{Cl}^{-}\right)$, sulfat $\left(\mathrm{SO}_{4}{ }^{2-}\right)$, dan bikarbonat $\left(\mathrm{HCO}_{3}{ }^{-}\right)$maupun tipe fluida hidrotermal dari mataair di sepanjang daerah Gedongsongo, Diwak, Derekan, Kaliulo, dan Banaran.

\subsection{Pembahasan}

Berdasarkan hasil analisis pada diagram ternary $\mathrm{Cl}^{-}-\mathrm{SO}_{4}{ }^{2-}-\mathrm{HCO}_{3}{ }^{-}[5]$, dapat dikelompokkan mataair yang berkembang pada kaki Gunung Ungaran bagian timur - selatan terdiri atas dua tipe fluida hidrotermal, yaitu: tipe Air Bikarbonatdan tipe Air Klorida. Perbedaan tipe fluida hidrotermal tersebut menunjukkan bahwa terdapat dua sumber fluida pembentuk manifestasi mataair sepanjang Gedongsongo, Derekan, Kaliulo, Banaran, dan Diwak berupa uap air panas dan air reservoir.

Tipe Air Bikarbonat merupakan tipe fluida hidrotermal pada mataair panas Gedongsongo, Derekan, Kaliulo, dan mataair Banaran (Gambar 3 dan 4). Tipe fluida ini, dicirikan dengan konsentrasi $\mathrm{HCO}_{3}{ }^{-}$yang tinggi dengan konsentrasi $\mathrm{Cl}^{-}$danSO ${ }_{4}{ }^{2-}$ relatif rendah (Tabel 2). Diperkirakan, fluida dengan tipe Air Bikarbonat terbentuk sebagai hasil dari uap panas ataupun kondensasi gas yang terakumulasi menjadi airtanah dangkal miskin oksigen. Pada manifestasi tipe Air Bikarbonat kerapkali disertai dengan pembentukan travertin, sebagaimana dijumpai pada lokasi disekitar mataair panas Derekan dan Kaliulo yang cukup intensif. Kehadiran travertin tersebut mengindikasikan daerah Gedongsongo, Derekan, Kaliulo, dan mataair Banaran memiliki temperatur bawah permukaan kurang dari $150^{\circ} \mathrm{C}$ [5]. Namun demikian, kondisi tersebut tidak dapat digunakan sebagai acuan kondisi geotermometer atau temperatur reservoir panasbumi tanpa adanya studi bawah permukaan lebih lanjut. Tipe Air Bikarbonat disebutkan sifat kimia fluidanya tidak selalu berkaitan dengan fluida reservoirnya, sehingga analisis geotermometer tidak dapat dilakukan [5]. Hal tersebut dapat dikarenakan sumber fluida berasal dari hasil lepasan akuifer dangkal ataupun akuifer dalam dengan sistem temperatur tinggi.

Tipe fluida hidrotermal berupa Air Klorida hanya dijumpai pada mataair Diwak. Tipe fluida ini, dicirikan dengan kandungan $\mathrm{Cl}^{-}$dominan, umumnya mengandung $1.000-10.000 \mathrm{ppm} \mathrm{Cl}^{-}[5]$. Pada tipe Air Klorida, konsentrasi sulfat dan bikarbonat relatif bervariasi, tetapi menunjukkan nilai jauh lebih rendah dari konsentrasi klorida. Sebagaimana ditunjukkan pada Tabel 1, mataair Diwak memiliki konsentrasi klorida sebesar 4.475 ppm, sedangkan konsentrasi sulfat dan bikarbonat kurang dari 4 ppm. Tipe Air Klorida, menunjukkan jenis fluida hidrotermal dalam dengan sumber fluida berupa air reservoir yang ditemukan pada sistem temperatur tinggi.Kehadiran tipe Air Klorida, pada umumnya mengindikasikan zona permeabilitas tinggi yang terbentuk oleh patahan, breksi hasil erupsi ataupun konduit. Selain itu, kehadirannya dapat digunakan dalam analisis geotermometer atau penentuan temperatur reservoir panasbumi.

\section{KESIMPULAN}

Hasil analisis tipe fluida hidrotermal menunjukkan mataair pada daerah penelitian memiliki Tipe Air Bikarbonat dan Tipe Air Klorida. Tipe fluida hidrotermal berupa Air Bikarbonat, dijumpai pada mataair Gedongsongo, Derekan, Kaliulo, dan Banaran dengan masing-masing anion utama pada ke-empat mataair tersebut 
memiliki nilai persen konsentrasi lebih kurang $0,5 \%-11,3 \% \mathrm{Cl}^{-} ; 2,7 \%-28,5 \% \mathrm{SO}_{4}{ }^{2-}$; dan $71 \%-96,7 \% \mathrm{HCO}_{3}{ }^{-}$. Hal ini mengindikasikansumber fluida hidrotermal terbentuk sebagai hasil akumulasi uap panas ataupun kondensasi gas menjadi airtanah dangkal yang miskin oksigen ataupun berasal dari hasil lepasan akuifer dangkal maupun dalam yang memiliki sistem temperatur tinggi. Kehadiran endapan travertin pada mataair Derekan dan mataair Kaliulo dapat mengindikasikan sistem temperatur pada sumber fluida kurang dari $150^{\circ} \mathrm{C}$. Namun, tidak dapat digunakan sebagai acuan kondisi temperatur reservoir panasbumi.

Tipe fluida hidrotermal berupa Air Klorida dijumpai pada Mataair Diwak. Tipe fluida ini dicirikan dengan konsentrasi $\mathrm{Cl}^{-}$yang tinggi sebesar $4.475 \mathrm{ppm}$. Adapun persen konsentrasi anion utama $\mathrm{Cl}^{-}$sebesar 99,8\%; $\mathrm{SO}_{4}{ }^{2-}$ dan $\mathrm{HCO}_{3}{ }^{-}$masing-masing sebesar $0,1 \%$. Tipe Air Klorida menunjukkan bahwa sumber fluida hidrotermal yang dalam dengan sistem temperatur tinggi. Kehadiran tipe fluida ini, disebutkan dapat digunakan sebagai acuan dalam analisis geotermometer atau temperatur reservoir panasbumi.

Adanya perbedaan tipe fluida hidrotermal pembentuk masing-masing mataair di sepanjang Gedongsongo, Diwak, Derekan, Kaliulo, dan Banaran dapat dipengaruhi oleh perbedaan susunan batuan di bawah permukaan yang memungkinkan untuk membentuk sistem hidrotermal berbeda maupun letak kedalaman akuifer atau sumber fluida. Kedepannya, dapat dilakukan penelitian dan pemodelan terkait kondisi bawah permukaan dari masing-masing lokasi mataair. Dengan demikian, dapat ditentukan variasi batuan bawah permukaan maupun model sistem panasbumiyang berkembang pada Gunung Ungaran, khususnya pada kaki Gunung Ungaran bagian timur - selatan, serta dapat ditentukan besar potensi panasbumi yang mungkin dihasilkan.

\section{UCAPAN TERIMAKASIH}

Ucapan terimakasih terutama ditujukan kepada Institut Teknologi Nasional Yogyakarta yang telah memberikan bantuan dana penelitian, sehingga penelitian dan analisis terkait dapat terlaksana dengan baik. Terimakasih disampaikan pula kepada Saudara Al-Hussein Flower R., S.T., M.Eng yang telah memberikan koreksi dan saran selama proses penulisan makalah ini. Selain itu, diucapkan terimakasih kepada rekan sejawat yang telah memberikan dukungan, sehingga makalah ini dapat terselesaikan dengan baik.

\section{DAFTAR PUSTAKA}

[1] K. Kusumadinata dkk, Data Dasar Gunungapi Indonesia, Indonesia: Departemen Pertambangan dan Energi, 1979.

[2] M. Nukman, Overview of Gedongsongo Manifestations of the Ungaran Geothermal Prospect, Central Java, Indonesia: a preliminary account,Proc. 34 Workshop on Geothermal Reservoir Engineering, Stanford: Stanford University, 2009.

[3] T.L.R. Astuti dan Ev.Budiadi, Geochemical of Soil at Gedongsongo Geothermal Prospect Area,Pros. Seminar Nasional RETII XII, Yogyakarta: ITNY,2017.

[4] R.E. Thanden dkk, Peta Geologi Regional Lembar Magelang dan Semarang,Skala 1: 100.000, Bandung: Pusat Penelitian dan Pengembangan Geologi, 1996.

[5] K. Nicholson, Geothermal Fluids Chemistry and Exploration Techniques, Berlin: Springer, 1993.

[6] B. Setiawan dan D. Purnomo, Validasi Metode HPLC untuk Analisis Sulfit Pada Pembuatan Kandidat SRM $\mathrm{NA}_{2} \mathrm{ZRO}_{3}$, Pros. Seminar Penelitian dan Pengelolaan Perangkat Nuklir, Yogyakarta: BATAN, 2012, hal 18 22.

[7] R.W. Van Bemmelen, The Geology of Indonesia,Vol 1A,Netherland: Martinus Nijhoff, The Hague,1949.

[8] J. Marin dkk,Studi Geomorfologi Gunung Api dan Petrogenesa Batuan untuk Memahami Evolusi Vulkanotektonik Pada Gunung Ungaran, Provinsi Jawa Tengah,Proc.Seminar Nasional Kebumian Ke 8, Yogyakarta: UGM,2015.

[9] Fatimah, Analisis Potensi Panas Bumi dengan Metode Geomagnet di Daerah Gedong Songo Ungaran Jawa Tengah,J. Ilmiah Bidang Teknologi, ANGKASA,vol. X, no. 1, Mei 2018, hal 9 - 16.

[10] Y.E. Sugiharto, The Ungaran Geothermal Field,Proc. Indonesian Petroleum Association-IPA31st Annual Convention and Exhibition, 2007. 
